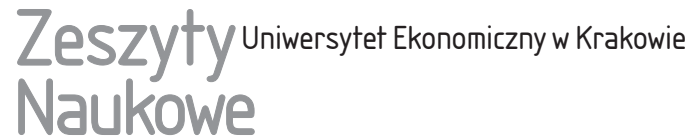

\section{Uwarunkowania lojalności klientów biur podróży}

\section{Streszczenie}

W artykule przedstawiono wyniki badań własnych, które pozwoliły na zidentyfikowanie kluczowych czynników warunkujących wystąpienie lojalności behawioralnej klientów biur podróży oraz opracowanie profilu lojalnego nabywcy usług biur podróży. Analizie poddano rzeczywiste dane historyczne, pochodzące z systemu księgowo-rezerwacyjnego jednej z ogólnopolskich sieci franczyzowych konsolidującej 60 biur agencyjnych, dotyczące 15248 rezerwacji dokonanych w latach 2013-2017 przez nabywców imprez turystycznych. W badaniu zależności zastosowano nieparametryczną metodę sztucznych sieci neuronowych, a najważniejszymi determinantami lojalności behawioralnej okazały się zmienne: czas trwania imprezy turystycznej, liczba dzieci poniżej 14. roku życia ujętych w rezerwacji oraz cena i miejsce docelowe imprezy turystycznej.

Słowa kluczowe: lojalność behawioralna, biuro podróży, nieparametryczne metody analizy danych, metoda sztucznych sieci neuronowych.

Klasyfikacja JEL: D12, M31.

\section{Wprowadzenie}

Problematyka lojalności nabywców ma zasadnicze znaczenie z perspektywy współtworzenia podstawowych kategorii ekonomicznych przedsiębiorstwa. Lojalność klientów wpływa na rezultaty finansowe przedsiębiorstw - wiąże się ona ze

Izabela Michalska-Dudek, Uniwersytet Ekonomiczny we Wrocławiu, Wydział Ekonomii, Zarządzania i Turystyki w Jeleniej Górze, Katedra Marketingu i Zarządzania Gospodarką Turystyczną, ul. Nowowiejska 3, 58-500 Jelenia Góra, e-mail: Izabela.Michalska-Dudek@ue.wroc.pl 
wzrostem obrotów (Hill i Alexander 2003) oraz obniżeniem kosztów (Reichheld i Sasser 1990), przyczyniając się ostatecznie do wzrostu zysków przedsiębiorstwa.

W kontekście działań zmierzających do budowania i wzmacniania lojalności klientów przedsiębiorstw turystycznych kluczowa staje się identyfikacja czynników wpływających na zachowania lojalnościowe klientów przedsiębiorstw turystycznych. Celem niniejszego artykułu jest identyfikacja uwarunkowań lojalności behawioralnej klientów biur podróży na przykładzie ogólnopolskiej sieci agencyjnych biur podróży.

\section{Przegląd literatury}

Lojalność klientów przedsiębiorstw turystycznych można zdefiniować jako głęboko utrwalone przekonanie nabywców do dokonywania powtórnych zakupów usług turystycznych albo stałe preferowanie określonych kategorii ofert turystycznych, których skutkiem są powtórne zakupy konkretnej marki lub pozycji z oferty przedsiębiorstwa turystycznego (lojalność behawioralna) oraz propagowanie pozytywnych opinii o określonym przedsiębiorstwie (lojalność afektywna), co odbywa się mimo wysiłków marketingowych konkurencji, mogących teoretycznie spowodować zmianę zachowania nabywcy (Michalska-Dudek 2017, Oliver 1999).

Lojalność nabywców względem przedsiębiorstw turystycznych uzależniona jest od wielu czynników, które składają się zarówno na uwarunkowania zachowań turystycznych, jak i na endogeniczne i egzogeniczne determinanty lojalności nabywców. Z jednej strony wpływają na nią cechy samego nabywcy, z drugiej - cechy branży turystycznej i specyficzne warunki rynkowe, w których funkcjonują podmioty działające na rynku turystycznym (szerzej w: Michalska-Dudek 2017, s. 59-65). Analiza zaprezentowanych w literaturze przedmiotu modelowych ujęć kształtowania lojalności klientów, a także przegląd prowadzonych badań empirycznych pozwoliły stwierdzić, że lojalność konsumentów wobec obszaru recepcji turystycznej (m.in.: Yoon i Uysal 2005; Hernández-Lobato i in. 2006, Albayrak i Caber 2008, Mechinda, Serirat i Gulid 2009, Seweryn 2012, Prayag i Ryan 2012, Lai i Vinh 2013, Haque i Khan 2013, Zong i in. 2014) i szeroko rozumianych usług noclegowych (Pritchard i Howard 1997, Back 2001, Bowen i Chen 2001, Kim i Han 2008, Correia Loureiro i Kastenholz 2011, Eid 2013, Movafegh i Movafegh 2013, Jani i Han 2014) często jest przedmiotem badań naukowych, natomiast badania lojalności klientów podmiotów zajmujących się organizacją i pośrednictwem na rynku turystycznym to zagadnienie najrzadziej analizowane. Potwierdza to potrzebę prowadzenia badań oraz podejmowania prób eksplikacji lojalności klientów biur podróży w Polsce. 


\section{Metodologiczne aspekty badań}

Sukces rynkowy przedsiębiorstw turystycznych zależy od zasobu wiedzy o klientach, która jest gromadzona i wykorzystywana w celu lepszego poznania i zaspokojenia potrzeb klientów. Źródłem wiedzy są dane o klientach, zawieranych przez nich transakcjach i zachowaniach ujawnionych podczas interakcji z przedsiębiorstwem. Możliwości poszerzania wiedzy szukać należy w nieparametrycznych metodach analizy danych ${ }^{1}$, które mogą być stosowane zarówno do eksploracji danych (data mining), jak i do konstruowania prognoz. Ważną cechą nieparametrycznych metod jest ich adaptacyjny charakter. Metody te polegają na doborze zmiennych do modelu przez optymalizację pewnego kryterium, zaś metody klasyczne wykorzystują z góry zadany zbiór predyktorów. Estymuje się wówczas zarówno postać modelu, jak i wartości jego parametrów (Gatnar 2001, s. 17).

Poszukiwanie determinant lojalności behawioralnej nabywców usług biur podróży wymagało zbudowania modelu, który uwzględniając rzeczywiste dane z przeszłości dotyczące cech, aktywności i historii zakupowej klientów, zakładał podział klientów na grupy o różnym poziomie zagrożenia rezygnacją z jednej strony i różnymi szansami na dalsze zakupy imprez turystycznych z drugiej strony. Zgodnie z podziałem metod wielowymiarowej analizy danych (Hair i in. 2010, s. 13) w przeprowadzonym badaniu zależności, w którym analizie poddano jedną zmienną zależną mierzoną na skali nominalnej - behawioralną lojalność klientów analizowanego biura podróży, wykorzystano metodę sieci neuronowych ${ }^{2}$.

Wzrost zainteresowania sieciami neuronowymi wynika z faktu, że należą one do metod analizy danych o dużych możliwościach aplikacyjnych (por. Lula, Paliwoda-Pękosz i Tadeusiewicz 2007, s. 78 i nast.). Okazały się one także narzędziem przydatnym do rozwiązywania wielu problemów badawczych w sytuacjach, w których potrzebne są metody modelowania umożliwiające odwzorowywanie złożonych - wielowymiarowych i nieliniowych - zależności. Szczególną właściwością sieci neuronowych jest to, że stanowią one odwzorowanie działania ludzkiego umysłu, implementując uproszczony matematyczny opis układu nerwowego.

${ }^{1}$ Zasadnicza różnica między metodami parametrycznymi a nieparametrycznymi polega na roli, jaką odgrywają w nich dane. O ile dla tych pierwszych dane są podstawą weryfikacji przyjętych wcześniej założeń, o tyle w przypadku tych drugich dane są systematycznie przeszukiwane w celu dokonania selekcji właściwych zmiennych oraz znalezienia informacji o postaci modelu. Metody nieparametryczne pozwalają przezwyciężyć ograniczenia klasycznych metod statystycznych i zbudować model bez znajomości postaci rozkładów cech oraz związków między nimi (Gatnar 2001, s. 8 i nast.).

${ }^{2}$ Ponieważ zaproponowana metoda ma charakter nieparametryczny, nie musiała być znana klasa funkcji opisujących wpływ predyktorów na zmienną wyjściową (y). Nie było również konieczne wcześniejsze dokonywanie specyfikacji predyktorów, jakie należy uwzględnić w modelu, a doboru zmiennych dokonuje się jednocześnie z budową modelu (por. Gatnar 2001, s. 29). 
Głównym zadaniem neuronów jest przetwarzanie informacji podanych na wejściu sieci w wartości wyjściowe. Sztuczne komórki nerwowe, wykorzystując wagi przypisane każdej informacji wejściowej, agregują dane wejściowe, a następnie wyznaczają wartości wyjściowe (Lula, Paliwoda-Pękosz i Tadeusiewicz 2007, s. 78-80).

Analiza rzeczywistych danych historycznych uwzględniających cechy, aktywność i historię zakupową klientów biur podróży pozwoliła na przeprowadzenie pogłębionej segmentacji, której efektem było również stworzenie charakterystyki lojalnego klienta biur podróży. Cechy lojalnego klienta biur podróży zostały omówione na podstawie rzeczywistych zachowań nabywców usług turystycznych na rynku, nie zaś badań ankietowych opierających się jedynie na deklaracjach konsumentów dotyczących procesu podejmowania decyzji o zakupie.

Badanie lojalności behawioralnej klientów biur podróży przeprowadzono, analizując rzeczywiste dane historyczne dotyczące przedsiębiorstwa turystycznego - Travel Shops Sp. z o.o. ${ }^{3}$, pochodzące z systemu księgowo-rezerwacyjnego. Dane te dotyczyły 15248 rezerwacji imprez turystycznych dokonanych przez klientów w latach 2013-2017 w ponad 60 agencyjnych biurach sieci franczyzowej na terenie całej Polski. Szczegółowym analizom współzależności występowania określonych zjawisk poddano 14000 rezerwacji, dla których możliwa była weryfikacja dokonania powtórnych zakupów usług turystycznych przez nabywcę.

\section{Analiza wyników badań}

Do podstawowego pomiaru lojalności behawioralnej nabywców usług badanego podmiotu zastosowano wskaźniki: utrzymania klientów (retention rate) oraz utraty klientów ${ }^{4}$. Na podstawie danych historycznych obliczono statystyczny wskaźnik utraty klientów, który wyniósł 68,83\% (Wskaźniki marketingowe... 2004, s. 75 i nast.), oraz wskaźnik utrzymania klientów (retention rate), utrzymujący się na poziomie 31,17\% (Wskaźniki marketingowe... 2004, s. 60 i nast.).

3 Travel Shops Sp. z o. o. z siedzibą w Łodzi to działająca na rynku od 2007 r. franczyzowa sieć agencyjnych biur podróży, konsolidująca ponad 60 biur agencyjnych w całej Polsce, prowadząca sprzedaż imprez turystycznych wielu organizatorów turystycznych. Zrzeszone w sieci biura agencyjne działają w ramach trzech modeli współpracy, jako: office partner, realizujący sprzedaż imprez turystycznych w lokalu usługowym; sprzedaż ta jest wsparta sprzedażą internetową, net partner, zajmujący się internetową sprzedażą imprez turystycznych (przez zindywidualizowany portal) bez lokalu usługowego, oraz mobile partner, sprzedający imprezy turystyczne bezpośrednio u klienta i/lub na spotkaniach.

${ }^{4}$ Pierwszy wskaźnik informuje, jaki procent klientów analizowanego przedsiębiorstwa turystycznego zrezygnował z jego usług, natomiast drugi wskaźnik określa, jaka część klientów, którzy dokonali zakupu usług firmy turystycznej w poprzednim okresie, ponowiła swój zakup. Oba wskaźniki ukazują procesy utraty i utrzymania klientów w dłuższym okresie, służąc jednocześnie do pomiaru skuteczności działań marketingowych (Wskaźniki marketingowe... 2004, s. 60 i nast.). 
Wartości obu wskaźników sygnalizują konieczność modyfikacji realizowanej przez analizowane przedsiębiorstwo strategii marketingowej oraz intensyfikacji działań mających na celu wzmocnienie lojalności klientów.

Na uwagę zasługuje struktura grupy lojalnych klientów badanego podmiotu. W analizowanym okresie 2013-2017 odnotowano 4363 przejawy lojalności behawioralnej, wyrażonej powtórnym zakupem imprez turystycznych w sieci biur podróży, z czego 76,19\% stanowiły zachowania lojalnościowe wobec 11 najważniejszych touroperatorów działających na polskim rynku. Ponad $40 \%$ odnotowanych przypadków wystąpienia lojalności behawioralnej klientów sieci dotyczyło czwórki największych organizatorów turystyki, a mianowicie takich biur podróży, jak: Itaka $(20,81 \%)$, TUI Poland $(8,27 \%)$, Grecos Holiday $(6,35 \%)$ oraz Neckermann Polska $(5,75 \%)$, zaś $13 \%$ przypadków klientów dokonujących ponownych zakupów dotyczyło zakupu imprez turystycznych i pakietów ubezpieczeń turystycznych (Signal Iduna Polska oraz Allianz). Świadczyć to może o fakcie, że nabywcy usług turystycznych - kierując się w swoich decyzjach zakupowych kryterium własnego bezpieczeństwa oraz pewności realizacji usług - wybierali dużych i wiarygodnych organizatorów podróży, a następnie powracali do nich.

W celu szczegółowej analizy zależności zastosowano nieparametryczną metodę analizy danych i na podstawie danych pochodzących z systemu księgowo-rezerwacyjnego badanej sieci biur podróży skonstruowano model oparty na sztucznych sieciach neuronowych ${ }^{5}$, przewidujący wystąpienie lojalności behawioralnej nabywców usług turystycznych.

Analizie poddano dane opisane poniższymi zmiennymi warstwy wejściowej:

1) rezerwacje:

- cena imprezy turystycznej - zmienna mierzona na skali ilorazowej $\left(x_{1}\right)$,

- sposób zakupu - zmienna mierzona na skali nominalnej $\left(x_{2}\right)$,

- forma płatności - zmienna mierzona na skali nominalnej $\left(x_{3}\right)$,

- liczba nabytych usług turystycznych - liczba osób objętych rezerwacją zmienna mierzona na skali ilorazowej $\left(x_{4}\right)$,

- liczba dzieci poniżej 14. roku życia ujętych w rezerwacji - zmienna mierzona na skali ilorazowej $\left(x_{5}\right)$,

- czas między datą rezerwacji a datą rozpoczęcia imprezy turystycznej - zmienna mierzona na skali ilorazowej $\left(x_{6}\right)$;

${ }^{5} \mathrm{~W}$ analizowanym przykładzie nie były znane zależności pozwalające na obliczenie danych wyjściowych na podstawie danych pochodzących z systemu księgowo-rezerwacyjnego sieci biur podróży, dlatego uznano za celowe zastosowanie sieci neuronowych. Przy budowie modelu neuronowego wykorzystano wyłącznie eksplorowane dane, a sieć neuronowa podlegała uczeniu w trybie z nauczycielem, służącym do modelowania nieznanej zależności (między zbiorem danych wejściowych a zbiorem zmiennych wyjściowych) i pozwalającym na wydobycie wiedzy zawartej implicite w eksplorowanych danych. 
2) imprezy turystyczne:

- organizator imprezy turystycznej - zmienna mierzona na skali nominalnej $\left(x_{7}\right)$,

- miejsce zakupu - agent sprzedający imprezę turystyczną - zmienna mierzona na skali nominalnej $\left(x_{8}\right)$,

- czas trwania imprezy turystycznej - zmienna mierzona na skali ilorazowej $\left(x_{9}\right)$,

- miejsce docelowe imprezy turystycznej - zmienna mierzona na skali nominalnej $\left(x_{10}\right)$;

3) charakterystyka klienta, w tym:

- miejsce zamieszkania klienta - zmienna mierzona na skali nominalnej (kod pocztowy $-x_{11}$ ),

- wiek klienta - zmienna mierzona na skali ilorazowej $\left(x_{12}\right)$,

- płeć klienta - zmienna binarna $\left(x_{13}\right)$.

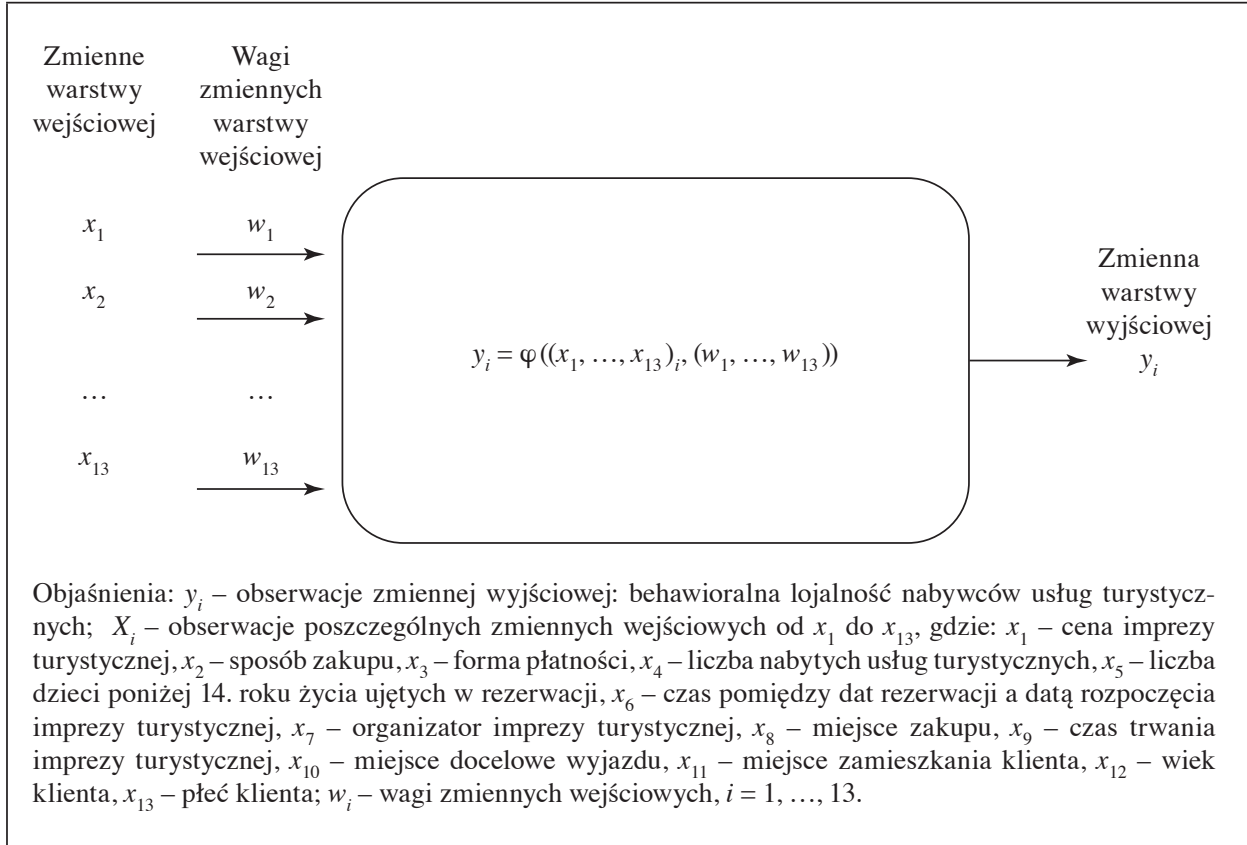

Rys. 1. Struktura modelu behawioralnej lojalności klientów badanego podmiotu opartego na sieci neuronowej typu MLP

Źródło: opracowanie własne.

Zmienną warstwy wyjściowej była behawioralna lojalność nabywców usług turystycznych $\left(y_{i}\right)$. Strukturę zaproponowanego modelu behawioralnej lojalności klientów badanego podmiotu opartego na sieci neuronowej typu MLP przedstawia rys. 1 . 
Opierając się na przedstawionych rzeczywistych przypadkach dotyczących dokonanych przez klientów biura podróży rezerwacji imprez turystycznych, zaproponowana sieć odkrywa ogólne prawidłowości kierujące przebiegiem zjawiska lojalności behawioralnej nabywców (zmienna warstwy wyjściowej $y_{1}$ ). Tak nauczona sieć ma również zdolność predykcji, którzy spośród dotychczasowych klientów dokonają ponownego zakupu ${ }^{6}$.

Do przeprowadzenia obliczeń w badaniu wykorzystano pakiet nnet środowiska R, wykorzystujący funkcję aktywacji softmax oraz algorytm uczenia wstecznej propagacji błędów (back propagation). Empiryczna weryfikacja teoretycznego modelu opartego na sztucznych sieciach neuronowych pozwoliła na identyfikację czynników determinujących lojalność behawioralną nabywców usług turystycznych badanego podmiotu.

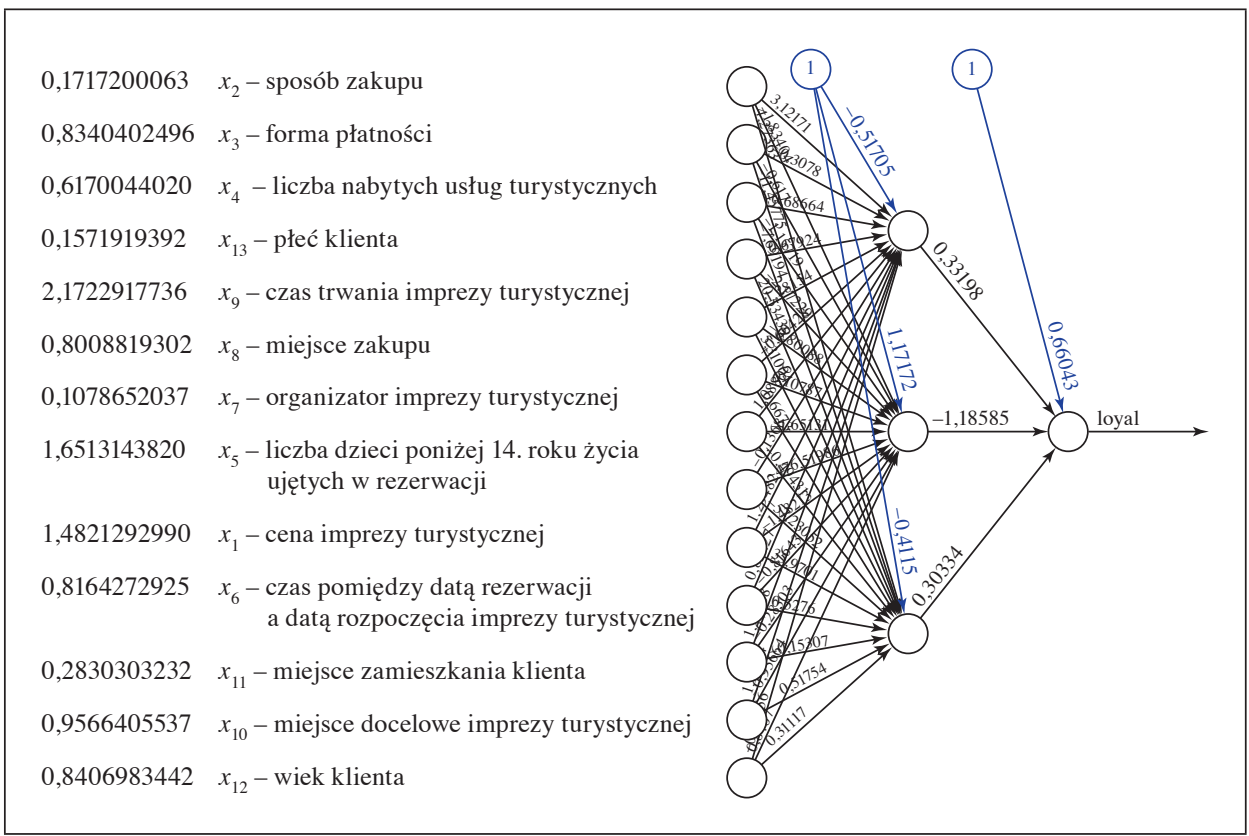

Rys. 2. Wyniki procesu uczenia się sieci z wykorzystaniem schematu z nauczycielem Źródło: opracowanie własne na podstawie przeprowadzonych badań i obliczeń z wykorzystaniem pakietu nnet środowiska R.

${ }^{6}$ Dla danych archiwalnych zmienna przyjmowała wartości: 0 - jeśli klient nie dokonał ponownego zakupu, lub 1 - jeżeli go dokonał. Dla nowych klientów była to zmienna z przedziału $\langle 0,1\rangle$ rozumiana jako prawdopodobieństwo dokonania ponownego zakupu po pierwszym zakupie. 
Obiekty z systemu księgowo-rezerwacyjnego (15 248 rezerwacji) podzielono arbitralnie na zbiór uczący i zbiór testowy. Zbiór danych wykorzystany w przeprowadzonym badaniu do uczenia sieci, zwany zbiorem uczącym, zawierał dane na temat 14000 rezerwacji?

W zbiorze tym odnotowano 4363 przypadków dokonania przez klientów ponownej rezerwacji i zakupu imprez turystycznych (wystąpienia lojalności behawioralnej).

Analiza ostatecznych wag przypisanych przez sieć neuronową poszczególnym zmiennym warstwy wejściowej (rys. 2) pozwala na sformułowanie wniosków dotyczących czynników determinujących wystąpienie lojalności behawioralnej nabywców usług turystycznych w analizowanym przedsiębiorstwie turystycznym.

\section{Wnioski}

Najważniejszymi determinantami lojalności behawioralnej klientów okazały się zmienne: czas trwania imprezy turystycznej $\left(x_{9}\right)$, liczba dzieci poniżej 14 . roku życia ujętych $\mathrm{w}$ rezerwacji $\left(x_{5}\right)$ oraz cena $\left(x_{1}\right)$ i miejsce docelowe $\left(x_{10}\right)$ imprezy turystycznej (rys. 3).

Za istotne uwarunkowania wystąpienia lojalności behawioralnej uznać należy również wiek klienta $\left(x_{12}\right)$ oraz czas pomiędzy datą rezerwacji a datą rozpoczęcia imprezy turystycznej $\left(x_{6}\right)$.

Wyniki przeprowadzonych analiz pozwalają na scharakteryzowanie lojalnego nabywcy usług turystycznych. Lojalni klienci analizowanej sieci biur podróży to osoby w średnim wieku (średnia wieku: 46 lat), bardzo często podróżujące z rodziną, w szczególności z dziećmi w wieku poniżej 14. roku życia, kupujące więcej usług turystycznych (dokonujące rezerwacji imprez turystycznych dotyczących kilku osób), wyjeżdżające na dłużej (ich wyjazdy to najczęściej imprezy 10-, 14-dniowe bądź dłuższe), a także planujące swoje wakacje i rezerwujące imprezy turystyczne z dużym wyprzedzeniem czasowym (średnio już $72 \mathrm{dni}$ przed terminem rozpoczęcia imprezy turystycznej, a najczęściej ok. 100 dni przed wyjazdem). Lojalni klienci średnio za imprezę turystyczną płacili 4652 zł/osobę, chętnie korzystali z ofert typu first minute, a najrzadziej ze wszystkich nabywców oczekiwali na okazje cenowe i wyprzedażowe oferty promocyjne last minute, co potwierdza, że ich lojalność wpływa na wyniki finansowe przedsiębiorstwa - przyczynia się do wzrostu obrotów (przychodów) z dokonywanych zakupów, a w konsekwencji do generowania zysków organizacji. Co więcej, ponad połowa

${ }^{7}$ Ze względu na brak możliwości potwierdzenia wystąpienia analizowanej prawidłowości (wystąpienia lojalności behawioralnej) w zbiorze uczącym oraz zbiorze testowym celowo pominięte zostały dane dotyczące 1248 rezerwacji z ostatnich miesięcy. 
lojalnych klientów to nabywcy imprez turystycznych do najbardziej popularnych destynacji turystycznych: Grecji (14,05\%), Hiszpanii (13,45\%), Turcji i Bułgarii (po 7,68\%), Egiptu (4,42\%) Włoch $(4,29 \%)$ oraz Tunezji $(2,68 \%)$. Lojalni klienci wybierają funkcjonujących od lat na rynku, wiarygodnych organizatorów imprez turystycznych o silnej pozycji konkurencyjnej, takich jak: Itaka $(20,81 \%)$, TUI Poland (8,27\%), Grecos Holiday (6,35\%) oraz Neckermann Polska (5,75\%).

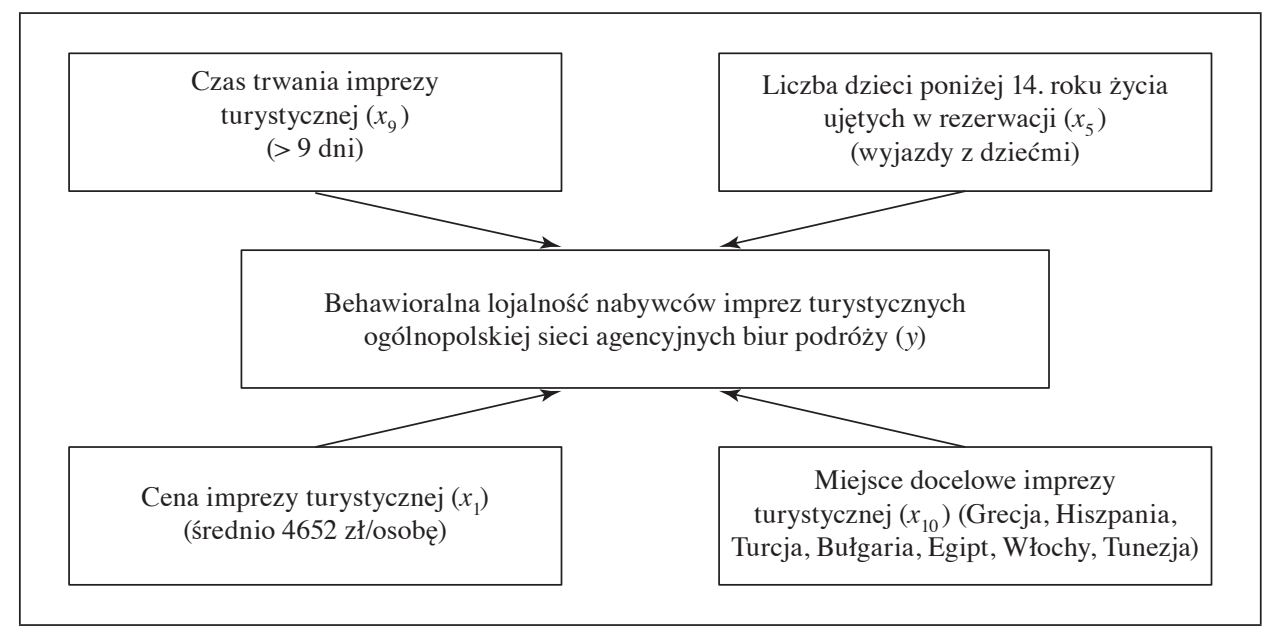

Rys. 3. Determinanty behawioralnej lojalności nabywców imprez turystycznych ogólnopolskiej sieci agencyjnych biur podróży

Źródło: opracowanie własne na podstawie przeprowadzonych badań i obliczeń z wykorzystaniem pakietu nnet środowiska R.

Ponieważ skuteczne budowanie lojalności nabywców usług biur podróży jest możliwe jedynie pod warunkiem znajomości przez menedżerów uwarunkowań postępowania nabywców, wyniki przeprowadzonych badań mogą być wykorzystane do identyfikacji grupy kluczowej dla badanego przedsiębiorstwa - lojalnych klientów - oraz dostrzeżenia wyróżniających ją cech. Działania mające na celu wzmocnienie lojalności powinny być adresowane do klientów dokonujących ponownych zakupów - klientów familijnych, w średnim wieku, wyjeżdżających na dwa tygodnie bądź dłużej, w towarzystwie rodziny, bardzo często z dziećmi poniżej 14. roku życia, planujących i rezerwujących swój urlop z dużym wyprzedzeniem, wybierających pewnych organizatorów imprez turystycznych i popularne destynacje turystyczne.

Implementacja działań zorientowanych na budowanie relacji powinna przejawiać się w bezpośrednim kontakcie z kluczowymi klientami, interaktywnej komunikacji z nimi, wczesnym rozpoznawaniu potrzeb analizowanej grupy, 
a także w tworzeniu zindywidualizowanych ofert. Identyfikacja, a następnie skuteczne zaspokojenie potrzeb tego szczególnego segmentu konsumentów poprzez uzyskanie gwarancji ponownych zakupów, a także minimalizacji ryzyka przyszłych działań marketingowych - pomogą umocnić pozycję konkurencyjną badanego podmiotu. Takie podejście pozwoli dowartościować klientów dokonujących ponownych zakupów, co może skutkować jeszcze większą ich lojalnością.

\section{Literatura}

Albayrak T., Caber M. (2008), Tourists' Satisfaction and Its Interaction with Loyalty towards to a Destination, Salamanca University, Salamanca.

Back K. (2001), The Effects of Image Congruence on Customer Satisfaction and Brand Loyalty in the Lodging Industry, The Pennsylvania State University, Pennsylvania.

Bowen J.T., Chen S. (2001), The Relationship between Customer Loyalty and Customer Satisfaction, „International Journal of Contemporary Hospitality Management”, vol. 13, nr 5, https://doi.org/10.1108/09596110110395893.

Correia Loureiro S.M., Kastenholz E. (2011), Corporate Reputation, Satisfaction, Delight, and Loyalty towards Rural Lodging Units in Portugal, ,International Journal of Hospitality Management", vol. 30, nr 3, https://doi.org/10.1016/j.ijhm.2010.10.007.

Eid R. (2013), Integrating Muslim Customer Perceived Value, Satisfaction, Loyalty and Retention in the Tourism Industry: An Empirical Study, ,International Journal of Tourism Research", vol. 17, nr 3, https://doi.org/10.1002/jtr.1982.

Gatnar E. (2001), Nieparametryczna metoda dyskryminacji i regresji, Wydawnictwo Naukowe PWN, Warszawa.

Hair J.F., Black W.C. Jr., Babin B.J., Anderson R.E. (2010), Multivariate Data Analysis, wyd. 7, Pearson Prentice Hall, Upper Saddle River.

Haque A., Khan A.H. (2013), Factors Influencing of Tourist Loyalty: A Study on Tourist Destinations in Malaysia, Proceedings of Third Asia-Pacific Business Research Conference 25-26 February 2013, Kuala Lumpur, Malaysia.

Hernández-Lobato L., Solis-Radilla M.M., Moliner-Tena M.A., Sánchez-García J. (2006), Tourism Destination Image, Satisfaction and Loyalty: A Study in Ixtapa-Zihuatanejo, Mexico, ,Tourism Geographies: An International Journal of Tourism Space, Place and Environment", vol. 8, nr 4, https://doi.org/10.1080/14616680600922039.

Hill N., Alexander J. (2003), Pomiar satysfakcji i lojalności klientów, Oficyna Ekonomiczna, Kraków.

Jani D., Han H. (2013), Personality, Satisfaction, Image, Ambience, and Loyalty: Testing Their Relationships in the Hotel Industry, ,International Journal of Hospitality Management", vol. 37, https://doi.org/10.1016/j.ijhm.2013.10.007.

Kim W., Han H. (2008), Determinants of Restaurant Customers' Loyalty Intentions: A Mediating Effect of Relationship Quality, ,Journal of Quality Assurance in Hospitality \& Tourism", vol. 9, nr 3, https://doi.org/10.1080/15280080802412727.

Lai W.H., Vinh N.Q. (2013), Online Promotion and Its Influence on Destination Awareness and Loyalty in the Tourism Industry, „Advances in Management \& Applied Economics", vol. 3, nr 3. 
Lula P., Paliwoda-Pękosz G., Tadeusiewicz R. (2007), Metody sztucznej inteligencji i ich zastosowania w ekonomii i zarzqdzaniu, Wydawnictwo Akademii Ekonomicznej w Krakowie, Kraków.

Mechinda P., Serirat S., Gulid N. (2009), An Examination of Tourists' Attitudinal and Behavioral Loyalty: Comparison between Domestic and International Tourists, ,,Journal of Vacation Marketing", vol. 15, nr 2, https://doi.org/10.1177/1356766708100820.

Michalska-Dudek I. (2017), Kształtowanie lojalności klientów biur podróży, Wydawnictwo Uniwersytetu Ekonomicznego we Wrocławiu, Wrocław.

Movafegh A., Movafegh A. (2013), The Impact of Service Quality on Tourist Loyalty in Malaysian Tourism Industry, ,International Journal of Innovative Ideas”, vol. 13, nr 1.

Oliver R.L. (1999), Whence Consumer Loyalty? „Journal of Marketing”, vol. 63, nr 4, https://doi.org/10.2307/1252099.

Pong L.T., Yee P.T. (2001), An Integrated Model of Service Loyalty, Academy of Business \& Administrative Sciences International Conferences, Brussels.

Prayag G., Ryan C. (2012), Antecedents of Tourists' Loyalty to Mauritius: The Role and Influence of Destination Image, Place Attachment, Personal Involvement, and Satisfaction, ,Journal of Travel Research”, vol. 51, nr 3, https://doi.org/10.1177/0047287511410321.

Pritchard M.P., Howard D.R. (1997), The Loyal Traveler: Examining a Typology of Service Patronage, ,Journal of Travel Research”, vol. 35, nr 4, https://doi.org/10.1177/ 004728759703500401.

Reichheld F.F., Sasser Jr. W.E. (1990), Zero Defections. Quality Comes to Service, „Harvard Business Review", nr 9-10.

Seweryn R. (2012), Kreowanie wartości dla klienta przez obszar recepcji turystycznej, Zeszyty Naukowe. Seria specjalna: Monografie, nr 220, Wydawnictwo Uniwersytetu Ekonomicznego w Krakowie, Kraków.

Wskaźniki marketingowe (2004), red. R. Kozielski, Oficyna Ekonomiczna, Kraków.

Yoon Y., Uysal M. (2005), An Examination of the Effects of Motivation and Satisfaction on Destination Loyalty: A Structural Model, ,Tourism Management”, vol. 26, nr 1, https://doi.org/10.1016/j.tourman.2003.08.016.

Zong H., Fu X., Cai L.A., Lu L. (2014), Destination Image and Tourist Loyalty: A Meta-analysis, „Tourism Management”, vol. 40.

\section{The Determinants of Travel Agency Client Loyalty}

(Abstract)

The article presents the results of the author's research identifying the key determinants of loyalty among travel agency clients. It also develops a profile of a loyal customer of travel agency services. The analysis covers real historical data, taken from the accounting and booking system of one nationwide franchise of networks in Poland consolidating 60 agency offices and referring to 15,248 reservations made in the years 2013-2017 by clients who purchased tourist services. A non-parametric method of artificial neural networks was applied, while the most important determinants of behavioural loyalty were the following variables: the duration of the tour, the number of children under the age of 14 included in the booking, the price and the destination of the tourist event.

Keywords: behavioural loyalty, travel agency, non-parametric methods of data analysis, MLP multilayer neural network. 